\title{
Perceptions and satisfaction of human-animal encounters in protected areas
}

\author{
Martina Dell'Eva \\ Free University of Bozen-Bolzano, Bolzano, Italy \\ Consuelo Rubina Nava \\ University of Aosta Valley, Aosta, Italy, and \\ Linda Osti \\ Faculty of Economics, Free University of Bozen-Bolzano, Bolzano, Italy
}

\begin{abstract}
Purpose - The purpose of this study is to assess the role of animals in creating a satisfactory experience at a natural park by investigating the impact on visitors of the exposure to, or absence of, fauna, towards the visitors' overall experience.

Design/methodology/approach - The work is based on a quantitative data collection of tourists visiting a nature park. Altogether, 532 valid questionnaires were collected and used for the analysis. A series of factor analyses was conducted on pull and push factors for animal encounters. The resulting factor domains (FDs) were used as independent variables in ordinal logistic regression models to describe customer satisfaction.

Findings - The results of this study show that important FDs characterize the main visitor characteristics. Although human-animal encounters are an important factor for some visitors, the encounters should be encouraged in the most natural manner possible and not in captivity. This brings us to the concept of "Interpretation", where guides and guided tours can help with the encounters. Information given prior to and during the visit can ensure visitors are aware that animal encounters are subject to nature and cannot be guaranteed.

Originality/value - The presence of areas where a number of animals are in captivity and can be viewed by visitors is an important decision for national parks and protected areas, as animals represent a potential attraction for visitors. Nevertheless, this decision creates an ethical dilemma in relation to the exploitation of animals, exacerbated by recent and increasing pressure on sustainable management. This study provides valuable results for guiding park managers in making reasoned decisions.
\end{abstract}

Keywords Protected areas, Wildlife tourism, Human-animal encounters, Nature parks

Paper type Research paper

\section{Introduction}

Humans and animals have always coexisted throughout millennia and our relationship with them is not something new (Orams, 2002). In a time of high urbanization where contact with wild animals is lost, the tourism industry has become a theatre for human-animal encounters by designing and offering "new sensory experiences" (Cohen, 2008, cited in

(C) Martina Dell'Eva, Consuelo Rubina Nava and Linda Osti. Published by Emerald Publishing Limited. This article is published under the Creative Commons Attribution (CC BY 4.0) licence. Anyone may reproduce, distribute, translate and create derivative works of this article (for both commercial and non-commercial purposes), subject to full attribution to the original publication and authors. The full terms of this licence may be seen at http://creativecommons.org/licences/by/4.0/legalcode 
WHATT

12,4
Duffy and Moore, 2011). Tourists are willing to travel long distances to pay to see animals in their natural habitat; in these contexts, animals become the focus of many different types of "must see" and "must do" activities. Animals can be observed freely in their natural environment, held in captivity (alive or dead), used as modes of transport, as icons at some destinations or as partners in long travel (Markwell, 2015). However, not all animals exert the same level of attraction for tourists and not all encounters are pursued with the desire for a "peaceful" interaction. At times, they become the object of culinary experiences, hunting trips or are seen as hazards and potential threats that need to be managed and controlled (Markwell, 2015).

In the tourism industry, animals have recently gained more attention and consideration because of man's shift of interest as to what constitutes a pleasurable leisure experience. This is because of recent changes in the human-animal relationship and increasing concerns for fair employment in tourism-based wildlife attractions (Carr, 2009). In addition, internet coverage and the extended reach of high-tech tools, such as general and social media, have encouraged the growth of this market, in times of alarm about environmental damage and habitat protection (UNWTO, 2015a). Man's disconnection from nature, caused by urbanization and isolation, has also led to a growing desire, and consequently demand, to reconnect with nature and interact with wild animals (Curtin, 2010a). In this regard, the term "biophilia" is used to identify man's inner drive to plunge into natural settings, i.e. the human tendency that longs for connection with nature and other living creatures (Wilson, 1993).

The desire by tourists to get closer to animals is also mirrored in the increasing dissemination of academic articles related to the importance of wildlife (Lovelock, 2008). In tourism studies, the interaction with animals is usually analysed from three perspectives (Rossell, 2017): ethics, tourism (focused on perceptions and attitudes of people towards animals, which are seen as important drivers to creating meaningful and memorable experiences) and management (characterized by its focus on the administration of animals, tourism activities and related offers) (Rossell, 2017).

This article will mostly address the second perspective. Despite the presence of a number of academic studies on tourist perspectives, many questions remain open and require further research.

Therefore, the main aim of this study is to investigate the role of animals in creating a satisfactory experience at a nature park by identifying the impact of exposure to, or the absence of, fauna, the perceived level of satisfaction about wildlife areas where animals are kept in captivity and an assessment of the overall experience.

\section{Wildlife tourism}

Wildlife tourism is the interaction with non-domesticated animals, either in captivity or in non-captive settings (Higginbottom, 2004). Wildlife tourism is on the rise. It is estimated that more than 10 million annual trips were made in 2014 (CBI, 2014, cited in UNWTO, 2015), with a (pre-Covid-19) predicted yearly growth rate of 10\% (UNWTO, 2015). This relatively new concept must be included in the literature on ecotourism and nature-based tourism (Fennell, 2008). There is no fixed or single orientation for the activities involved; it derives from "natural area tourism", which focuses on wildlife observation and the appreciation of landscapes in nature (Newsome et al., 2002). To provide a general idea in number terms, recent findings in wildlife tourism attractions estimate that around 5 million tourists travel annually to see around 236,000-561,000 animal species (Moorhouse et al., 2015). These tourists have quite heterogeneous demands and characteristics. Some tourists prefer to experience the wild while backpacking, others prefer to enjoy the wilderness by staying at expensive resorts and hotels and finally, others prefer observing animals while traveling on cruise ships and boats (Shackley, 1996). Activities are characterized by different levels of involvement, length of the encounter and types of animals involved (Curtin, 2010a). Passive 
forms of wildlife tourism involve the observation of animals in free settings, captive encounters and in unnatural manmade sites such as zoos or sanctuaries. Active forms include hunting and fishing tourism (Higginbottom, 2004). The latter type of tourism is seen as a consumptive approach that is quite removed from more sustainable forms, such as ecotourism. Thus, ecotourism and wildlife tourism are terms that cannot be used interchangeably (Fennell, 2008).

\section{Wildlife encounters in protected areas}

Nowadays there are many opportunities to interact with wild animals, either in captivity or free settings. The demand for experiences in the wild has, in fact, been increasing (Rodger et al., 2007) because of a detachment from nature, and the desire for memorable or "peak" experiences. These experiences are exciting and thrilling; they make people feel fulfilled and euphoric in having done something exceptional (Shackley, 1996), and attract tourists to national parks (Scholtz et al., 2013, cited in Mutanga et al., 2017). The presence, or visibility of wildlife, is an important component of the recreational activities in natural reserves or parks (Newsome et al., 2002) and research conducted in the USA and Western Australia revealed how the observation of wildlife in natural settings can add value to the overall recreational experience (Newsome et al., 2002).

However, the experience is not always, or not only about sighting animals; these types of experiences could also be chosen for the sense of wilderness they inspire and for the beauty of the natural environment (Balmford et al., 2015). Visitors could also be attracted to the location for the pleasure of discovering a new place, by the interesting trails for hiking and trekking (Oh and Hammitt, 2010), and by the opportunity to take unique photographs (Shackley, 1996). The desire to relax, to spend time with other people, to learn something from nature and to visit a precious place in terms of personal attachment are other important driving factors for visiting natural areas (Pan and Ryan, 2007). The desire to get away from cities, to be close to nature, to relax and to recover from the daily stress, can be denoted as "push factors" - variables that help people to escape from their usual leisure routine. In contrast, "pull factors" towards protected areas and national parks include the authenticity of a place and its beauty and scenery (Mutanga et al., 2017). They represent those aspects that literally "pull" tourists towards the destination. These aspects should be responsibly exploited by tourism providers to gain a powerful competitive advantage. Pull factors are related to specific attractions or features at the destination (Hsu et al., 2009). They emerge as part of the attractiveness of a place and constitute physical elements that build up its identity (Baloglu and Uysal, 1996, cited in Aref and Puad, 2010). In fact, identifying what drives and motivates tourists is essential in developing good marketing tools and in implementing strategies for any type of destination (Pan and Ryan, 2007).

Visitor satisfaction of protected areas is shaped and influenced by the situations and experiences people have in these natural settings and from the benefits they receive from such areas, which consequently help to form their opinion of the place (Bigne et al., 2005). High levels of satisfaction encourage people to come back for future visits (Tian-Cole et al., 2002). The more benefits visitors receive during their visit, the more satisfied they are and the higher the propensity to return (Scott et al., 1995, cited in Arabatzis and Grigoroudis, 2010).

Managing resources and activities in protected areas is a very challenging task: managers should be able to identify visitors' prior expectations, motivations and sources of satisfaction and dissatisfaction (Fennell, 2008). Tourists who are consistently interested in living "meaningful experiences", have become more engaged with learning and the educational aspects of their visits and often search for meaning in the activities they choose to undertake (Eagles et al., 2000, cited in Mutanga et al., 2017). This aspect can be identified 
WHATT

12,4

444

as "Interpretation". Interpretation in natural areas has gained importance as people seem to look for meaning and for more significance in relation to their visit (Newsome et al., 2002). Interpretation can basically be expressed as an educational activity, which is used to communicate, share ideas and find deeper meaning; it is a tool for enriching the visitors' overall experience (Newsome et al., 2002). Its role is to enhance one's personal learning experience and knowledge, especially in relation to the environment as this process can lead to a deeper understanding of the fragility and importance of wildlife as a resource (Boemah, 2011, cited in Mutanga et al., 2017). One of the mechanisms used to understanding the wilderness areas is the presence of visitor centres, mostly located at the entrance of nature protected areas and designed to offer information relating to flora, fauna and its management. In the pre- or post-visit, through the development of themes, visitors are introduced to the world of the wildlife and they learn from the educational materials on display such as photographs, detailed descriptions on panels, scale models and audio-visual displays (Newsome et al., 2002).

When considering the actual, physical, access to nature parks, experiences can be offered in many forms to provide an opportunity to approach a variety of animals at very close range (Fredline and Faulkner, 2002, cited in Mutanga et al., 2017). Yet, not having the possibility to see and interact with animals can detract from the experience (Mutanga et al., 2017). In addition, the perceived degree of safety is also considered a variable that will determine overall satisfaction or dissatisfaction. The ability to control the degree of safety is represented by the presence of a guide with specific knowledge of the situation, and can also be beneficial in terms of interpretation (Newsome et al., 2002). The guide can personalize the experience, making it more unique and appealing to visitors (Shackley, 1996). Other factors that can determine the level of control are the requirements to obey specific rules and the degree of exposure to animals (Reynolds and Braithwaite, 2001). Park managers, in fact, might limit the intrusion of visitors, to minimize the potential impact on the environment and its inhabitants (Pitt and Zube, 1987, cited in Fennell, 2008). The regulatory behaviour in parks might consist of: closing trails, prohibiting the circulation of cars and restricting access to specific areas during particular periods, for instance where animals usually congregate (i.e. watering holes). In addition, the presence of other people, the over commercialization of an area and its excessive popularity can negatively influence the quality of the wilderness experience. This is called a "conflict of use" problem (Shackley, 1996). In addition, the same observer, with his or her level of knowledge of the specific context, degree of motivation and level of education, can influence and shape the final considerations of the trip (Reynolds and Braithwaite, 2001). It is interesting to note that experiences in the wilderness can simultaneously include both satisfied and dissatisfied visitors. In fact, some studies show that people can be both very satisfied overall, even if they experienced "at least one dissatisfying incident during their visit" (Graefe et al., 1984, cited in Fennell, 2008).

To summarize, parks deserve special attention as tourism products (Shackley, 1998, cited in Reinius and Fredman, 2007) and can represent an optimal place for human-wild animal encounters, thus representing the essence of the wildlife experience (Mutanga et al., 2017). In fact, the observation of wildlife is believed to be one of the main reasons for visiting protected areas (Scholtz et al., 2013, cited in Mutanga et al., 2017). Nature parks, thanks to their wildlife, could structure and base their offer on learning and educational aspects (Kamri and Radam, 2013). One practice usually adopted in protected areas, and frequently applied in ecotourism contexts, is the interpretation technique, a soft type of management technique that helps support more formal management programmes by educating visitors (Fennell, 2008). 
This article is the result of a research study conducted at the Nature Park "Fanes - Senes Braies" in northern Italy, in the Alpine province of Bolzano (South Tyrol). With its multitude of habitats, this nature park is home to many species of flora and fauna. The park was established in 1980 and is one of the "Natura 2000" sites of the EU programme. It is an outstanding and valuable natural resource, embedded in the Dolomites, and in 2009 both were recognized as UNESCO World Heritage Sites.

The recognition obtained, in the summer of 2009, as a unique UNESCO World Heritage

Site for the scenic beauty of this mountainous area (Autonomous Province of Bozen/ Bolzano, 2019), makes the park more vulnerable to human over-crowding. While visiting the park, observing wild animals in their natural environment may be difficult, so an opportunity to appreciate the secrets of the local wildlife is offered at the Nature Park Visitor Centre, or "Naturparkhaus". The structure is located in the municipality of San Vigilio di Marebbe. The Centre is open from early May to the end of October and provides an interactive overview of wild species, legends and curiosities. Thanks to interactive materials, videos, audios, panels, embalmed animals and other educational tools, visitors have the opportunity to study this distinctive mountain landscape and its inhabitants (Autonomous Province of Bozen/Bolzano, 2013).

From mid-May to the end of August 2019, 606 questionnaires were collected. Out of these questionnaires, 532 were used for the analysis; 74 questionnaires were excluded because they were incomplete. The data collection took the form of self-administered paper and online questionnaires. Paper questionnaires were $49 \%$ of the sample. The paper-based sample is composed of visitors to the Fanes - Senes - Braies Park who were interviewed at different spots (the Visitor Centre and three different mountain huts) inside the park. Online respondents were Instagram users (people who had posted pictures of the park in previous weeks) and Facebook users (who had commented and posted pictures of their park visit in the summer of 2019).

The questionnaire was prepared in Italian, German and English to reach the broadest possible range of visitors. Indeed, more than $80 \%$ of the visitors were from Germany and Italy, with a higher percentile of Italians in the summer months. On average, it took between 6 and $8 \mathrm{~min}$ to complete the questionnaire. The questionnaire consisted of 20 close-ended questions, divided into 4 main parts. The first part was dedicated to questions about the respondent's visit to the park and the pull and push factors for the visit. The second part focused on the encounter with animals and the degree of satisfaction with such encounters. The third part included questions on factors that could increase the attractiveness of the park such as wildlife areas and measures that visitors were willing accept to protect the wildlife. The last section was dedicated to socio-demographic questions. Questionnaire scales were derived from the literature and a five-point Likert scale was used. In particular, the following articles were assessed prior to creating the scales: Moscardo (2008), Mutanga et al. (2017) and Ballantyne et al. (2018).

\section{Results}

Analysis of the 532 completed responses revealed that the mean age of the sample was 43 years and mostly composed of women $(65 \%)$. The majority of the respondents $(87 \%)$ were Italian citizens, followed by Germans $(9.6 \%)$, and the remaining $3.4 \%$ were other nationalities. The majority of the visitors had previously been to the park (90\%) and $43.2 \%$ had visited five or more times. The park is principally known through word of mouth $(29.5 \%)$ and $64.5 \%$ of the sample had already visited other national/nature parks in the previous five years. 
WHATT

12,4

446

Push and pull factors were investigated, using appropriate five-point Likert scales. When considering the pull factors, $96.3 \%$ rated it important or very important, to admire the beauty of the landscape, followed by the possibility to see wild animals or visit a specific spot South Tirol (63.3\% important/very important for both factors). Regarding push factors, the most important factor was to stay in touch with nature (96.1\% important/very important), followed by exploring a natural context, escape from daily routine, having fun and relaxing and getting away from the chaos of the city $(92.5 \%, 83.9 \%, 83.7 \%$ and $78.4 \%$ of respondents rated these factors, respectively, as important/very important). Other push factors (to photograph animals/ nature and undertake sport and staying with the family) were less important for respondents. Further descriptive statistics can be found in Appendix.

\section{Factor domain creations}

To profile respondents and to understand the role of different aspects of customer satisfaction, we undertook four factor analyses (FA) with varimax rotation. On the basis of the results of FA, we constructed different factor domains (FD) of different scales to summarize respondents' degree of perception towards the park and the animal encounters. This information was used to describe the satisfaction determinants and the importance of creating a wildlife area.

\section{Push and pull factors}

We first conducted a FA on push and pull factors. It resulted in a three-factor solution, which explains $59.24 \%$ of total variance. Items communality is always $>0.40$ and no items load on more than one factor (at $>0.40$ ). On the basis of each FD composition, we labelled them: Nature, Escape and Explore, respectively (Figure 1). The Explore factor is principally driven by pull factors, while Nature and Escape by push factors. The overall Cronbach's alpha is equal to 0.89 , which confirms the FA's reliability. Visiting the park is mainly justified by the necessity to stay and experience nature, followed by the need to rest, escape from the daily routine and, finally, the desire to explore a mountain destination, to potentially see wild animals and possibly capture them on camera.

Figure 1.

FA of push and pull factors

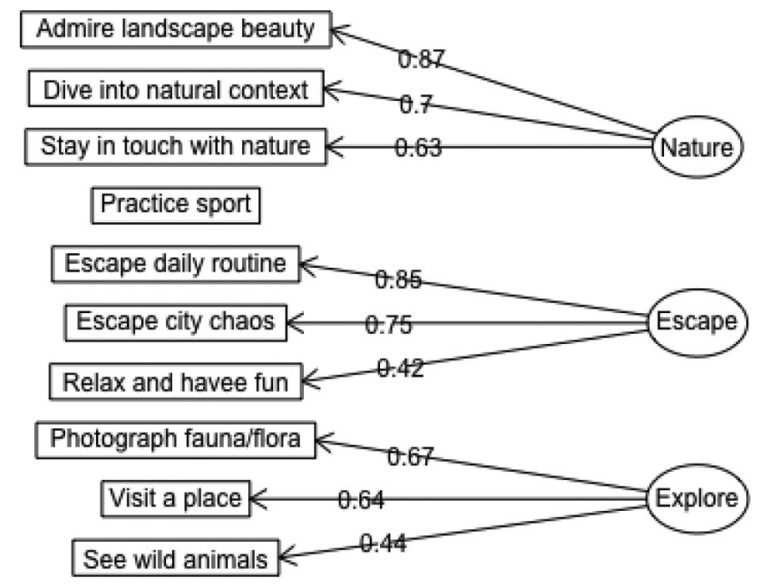

Spend some time with family

Note: Values on arrows are loadings on each FD 
It is important to understand the considerations that drive satisfaction with respect to the wild animal experience. The possibility to observe animals in their natural habitat $77 \%$ rate important/very important) seems to be the most important factor, followed by the visitor's safety in that encounter (59\% important/very important) and the possibility to come across a wide variety of species (52\% important/very important). The FA conducted on this scale (Figure 2) results in two FDs, accounting for $69.12 \%$ of the total variance. Items communality is $>0.40$ and no items load on more than one factor. The overall Cronbach's alpha is equal to 0.97. FDs are labelled Easy and Species, respectively. Indeed, the first factor is mainly based on the possibility to easily see or approach animals, while the second refers to the quantity and the variety of species. Both Easy and Species domains have only a few associated categories with Explore (correlation is 0.30 and 0.31, respectively).

\section{Wildife encounter}

Respondents also expressed preferences about the possibilities of encountering wildlife. They prefer to see endangered species in long encounters. In this case, we also conducted FA (items communality is $>0.40$ and no items load on more than one factor) that generated a unique factor representing the $53.49 \%$ of the total variance with a Cronbach's alpha equal to 0.83. This FD, labelled Encounter, mainly loads on the longer encounters, with big and wellknown animals (Figure 3 ).

\section{Willingness to revise the rules regulating the visit/stay}

Finally, FA was conducted with respect to the willingness to revise the rules regulating the visit/stay during the visitor's experience of nature. A unique FD emerged, accounting for $60.74 \%$ of the total variance with an overall Cronbach's alpha of 0.85 . It is labelled Rules, and loads on the possibility "to forgo the opportunity to visit some areas during predetermined periods" and "to reduce the number of sporting activities with the highest impact on fauna" (Figure 4).
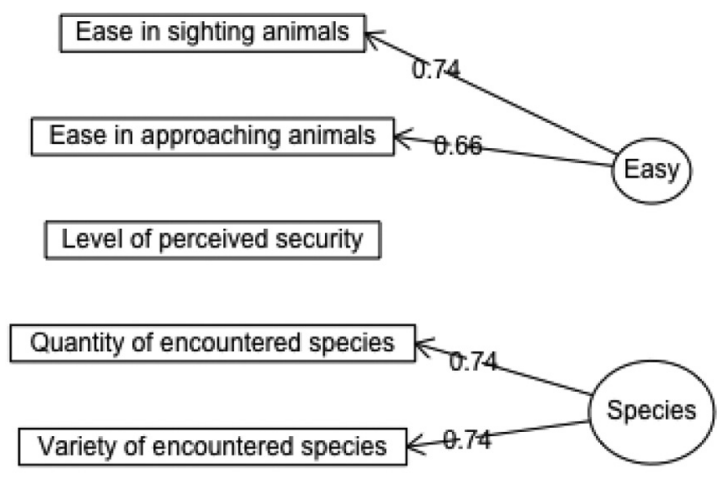

Observe animals in their natural habitat

Note: Values on arrows are loadings on each FD

Figure 2. FA of determinants who have a satisfying experience with wild animals 


\section{WHATT}

12,4

448

Figure 3.

FA of preferences concerning possible encounters with wildlife

\section{Figure 4.}

FA of the willingness to revise the rules for visiting/staying at the park

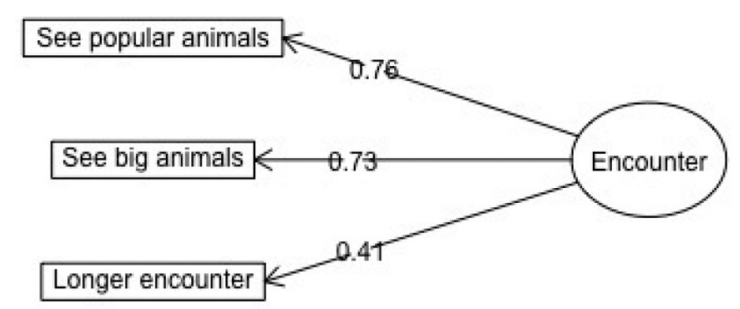

See dangerous animals

See endangered species

Note: Values on arrows are loadings on each FD

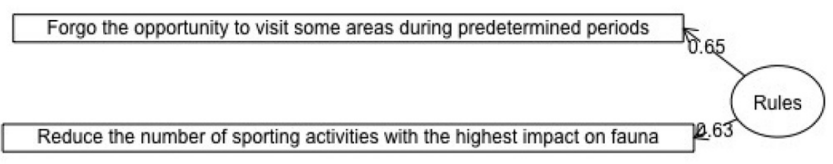

Reduce car/motorbike speed in the natural Park

Participate to conservation projects

Note: Values on arrows are loadings on each FD

\section{Econometric analyses}

The FDs that emerged from the four FAs are crucial in identifying the determinants of respondents' satisfaction and the importance of creating wildlife areas at different levels. The first discriminatory aspect used to evaluate visitors' satisfaction of their experience at the nature park is having had an actual encounter with wild animals (true for $55.7 \%$ of the sample). According to this specification, the sample was split in two parts, of which specific analyses were conducted to study the satisfaction determinants.

The results of the different ordinal logistic regressions conducted on these two subsamples follow in Table 1 as well as on the entire sample (Table 2) with dependent and independent variables. Dependent variables are always items with a five-point Likert scale, and determined the choice of the econometric model. Independent variables can be grouped in two sets: the first refers to the emerging FDs, previously obtained, while the second represents the respondents' personal information, such as gender, age and education.

When respondents did not encounter animals, the probability of being dissatisfied increased with the Encounter and Explore FDs, while it reduced according to the Rules FD (Table 1, Model 1). In other words, the level of satisfaction decreased in respondents driven 


\begin{tabular}{|c|c|c|c|c|c|c|}
\hline \multirow[b]{2}{*}{ Covariates } & \multicolumn{2}{|c|}{$\begin{array}{c}\text { Model 1 "I am } \\
\text { dissatisfied (did not see/ } \\
\text { encounter wild animals)" }\end{array}$} & \multicolumn{2}{|c|}{$\begin{array}{l}\text { Model } 2 \text { "I am curious to } \\
\text { meet animals (did not see/ } \\
\text { encounter wild animals)" }\end{array}$} & \multicolumn{2}{|c|}{$\begin{array}{l}\text { Model } 3 \text { "I am more } \\
\text { satisfied (saw/interacted } \\
\text { with wild animals)" }\end{array}$} \\
\hline & Coef. & Std error & Coef. & Std error & Coef. & Std error \\
\hline Nature & -0.029 & 0.254 & 0.056 & 0.234 & $0.779 * * * *$ & 0.279 \\
\hline Escape & -0.380 & 0.236 & -0.101 & 0.217 & -0.227 & 0.219 \\
\hline Explore & $0.456^{*}$ & 0.234 & 0.272 & 0.194 & -0.003 & 0.180 \\
\hline Easy & 0.547 & 0.416 & 0.440 & 0.378 & 0.060 & 0.352 \\
\hline Species & -0.281 & 0.420 & -0.290 & 0.383 & 0.463 & 0.347 \\
\hline Encounter & $0.557 * * *$ & 0.165 & $0.616^{* * *}$ & 0.148 & 0.065 & 0.139 \\
\hline Rules & $-0.315 * *$ & 0.130 & $0.318^{* * * *}$ & 0.121 & 0.171 & 0.134 \\
\hline Male & $0.551 *$ & 0.300 & 0.234 & 0.269 & -0.165 & 0.252 \\
\hline Higher education & -0.140 & 0.288 & -0.333 & 0.263 & -0.327 & 0.243 \\
\hline Age & -0.001 & 0.009 & $-0.022^{* * * *}$ & 0.008 & -0.010 & 0.007 \\
\hline Strongly disagree / disagree & 0.396 & 0.480 & $-3.126^{* * * *}$ & 0.493 & $-5.468^{* * * *}$ & 0.700 \\
\hline Disagree|neutral & $1.523 * * * *$ & 0.490 & $-2.199 * * *$ & 0.467 & $-4.099 * * *$ & 0.492 \\
\hline Neutral|agree & $2.482 * * * *$ & 0.513 & $-1.175^{* * *}$ & 0.453 & $-2.100^{* * *}$ & 0.391 \\
\hline Agree| strongly agree & $3.643^{* * * *}$ & 0.578 & 0.306 & 0.447 & -0.208 & 0.366 \\
\hline AIC & \multicolumn{2}{|c|}{506.47} & \multicolumn{2}{|c|}{648.99} & \multicolumn{2}{|c|}{618.005} \\
\hline Observations & \multicolumn{2}{|c|}{236} & \multicolumn{2}{|c|}{236} & \multicolumn{2}{|c|}{296} \\
\hline
\end{tabular}

Notes: Significance levels $* * *(<0.01) ; * *(<0.05)$; and $* *(<0.10)$ protected areas dissatisfied (did not see/ meet animals (did not see/ satisfied (saw/interacted

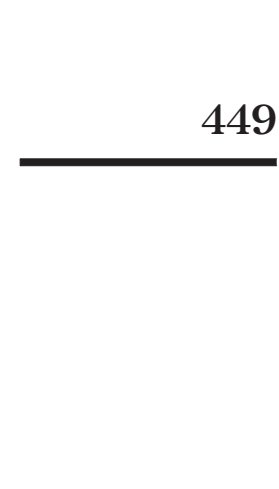

Table 1. Ordinal logistic regressions

\begin{tabular}{lcc}
\hline Covariates & Coef. & Std error \\
\hline Nature & $-0.251^{*}$ & 0.145 \\
Escape & 0.146 & 0.154 \\
Explore & 0.143 & 0.131 \\
Easy & $0.212^{* * *}$ & 0.101 \\
Encounter & $0.385^{* * *}$ & 0.098 \\
Rules & $0.074 * .54^{* * *}$ & 0.088 \\
Overall satisfaction: very satisfied & $-0.558^{* *}$ & 0.196 \\
Overall satisfaction: satisfied & $-0.749^{*}$ & 0.443 \\
Overall satisfaction: not satisfied & 0.159 & 0.902 \\
Overall satisfaction: not at all satisfied & $-13.524^{* * *}$ & 0.000 \\
Animal encounter: yes & -0.013 & 0.171 \\
Not at all important | not important & $-1.074^{* * * *}$ & 0.205 \\
Not important| neutral & -0.03 & 0.199 \\
Neutral| important & $0.697^{* * * *}$ & 0.202 \\
Important| very important & $1.629^{* * * *}$ & 0.22 \\
AIC & 1423.999 & \\
Obs. & 532 &
\end{tabular}

Table 2. Ordinal logistic regression on the importance of creating wildlife areas

by pull factors, with a high propensity to explore and experience the natural context. Similarly, the level of satisfaction decreased when respondents highly rated wildlife encounters with particular attention to long encounters with big and popular animals. However, the degree of satisfaction increased according to the possibility of visiting certain areas during specifically predetermined periods to reduce the number of sporting activities 
WHATT

12,4 with the highest impact on fauna. Finally, males on average had a lower degree of satisfaction. The other FDs and personal data did not have a statistically significant impact on satisfaction.

Moreover, considering the same sub-sample of respondents, the probability of returning in the future, out of curiosity and to see wild animals increased with the Encounter and Rules FDs (Table 1, Model 2). Intuitively, if animal encounters are quite important for visitors, they will have a higher propensity to come back, even if they did not see wild animals on the given trip. The probability decreased, however, as the age of the respondent increased. Other determinants had a statistically insignificant impact. Also, when respondents encountered animals, the probability of being satisfied increased with the Nature FD (Table 1, Model 3). Namely, respondents who rated highly the possibility to stay in touch with nature, dive into a natural context and admire a beautiful landscape, were more satisfied.

Finally, the importance of creating wildlife areas was studied in Table 2. When respondents gave high ratings to items within the Nature FD, the probability that they gave importance to the creation of wildlife areas decreased. Differently, this probability increased with the Easy and Encounter FDs. In other words, when a respondent considered it crucial to have an easy encounter with animals, it resulted in the propensity to see animals also in wildlife areas. Similarly, when long encounters, with big and well-known animals were desired, it led to an increase given to the importance of having wildlife zones. Regarding satisfaction with the overall experience, higher levels of satisfaction were associated with lower levels of importance attributed to the creation of wildlife zone, compared to neutral satisfaction. The estimated coefficient for "not at all satisfied" only referred to a single respondent.

In the four models proposed in Tables 1 and 2, differential intercepts are almost always statistically significant.

\section{Conclusion}

Dedicating areas with a number of wild animals in captivity to be viewed by visitors is an important decision that managers of national parks and protected areas must consider, as they represent a potential attraction for visitors. Nevertheless, this decision poses an ethical dilemma in relation to the exploitation of animals and the recently increasing pressure for sustainable management. Therefore, understanding the perceptions and the expectations of visitors to take effective managerial and marketing decisions has become necessary.

This article sought to investigate the role of animals in creating a satisfactory experience at a nature park, by identifying the impact of exposure, or lack of, to fauna and investigate the perceived attraction of wildlife areas with animals kept in captivity, towards the visitor's overall experience. The study was conducted at a natural park where a designated wildlife zone for visitors to view/interact with animals is not present. Instead, animals can be seen only in the wild, which is a situation that does not assure animal spotting at each visit.

Results of this study show that visitors who were attracted to the park to explore the place (take pictures, visit a specific area and see wild animals) or see popular and big animals and have longer encounters with them, and were ready to forgo some of their behaviours to protect the animals, were more likely to feel highly dissatisfied if they did not encounter animals. Nevertheless, those same visitors, who preferred to see popular and big animals and have longer encounters with them, and who were ready to forgo some of their behaviours to protect the animals, were willing to return to the park for another chance to see them. Furthermore, visitors who visited the park, attracted by the nature and beautiful landscapes, were more likely to feel very satisfied when they encountered animals. 
Wildlife sighting and encounters during the visit was an important factor but it only provided extra satisfaction for some of the visitors. Nonetheless, the lack of encounters created dissatisfaction. For this reason, park managers are faced with a decision as to whether to offer a designated area for the observation of wildlife in captivity or leave the encounters as casual and natural as possible. Our analysis shows that while wildlife areas are considered an important part of the park experience for visitors (those who consider the encounter with the animals as important), the level of overall satisfaction is not associated with the presence of a wildlife area. In fact, those with a higher degree of satisfaction with the park attached less importance to the development of a wildlife zone as an attraction factor.

These results show that although human-animal encounters are an important factor for some visitors, the encounter should be encouraged in the most casual and natural way rather than in captivity. This brings us back to the concept of "Interpretation" (Newsome et al., 2002; Newsome and Hassell, 2014; Mutanga et al., 2017), where guides and guided tours can help in such encounters. Information, at visitor centres and throughout the park, given prior and during the visit can make visitors aware that animal encounters are subject to nature and cannot be guaranteed.

\section{References}

Arabatzis, G. and Grigoroudis, E. (2010), "Visitors' satisfaction, perceptions and gap analysis: the case of Dadia -Lefkimi - Souflion national park", Forest Policy and Economics, Vol. 12 No. 3, pp. 163-172.

Aref, B. and Puad, A. (2010), "An analysis of push and pull travel motivations of foreign tourists to Jordan”, International Journal of Business and Management, Vol. 5 No. 2.

Autonomous Province of Bozen/Bolzano (2019), "Fanes - Sennes - Prags/Fanes - Senes - Braies nature park", available at: https:/nature-parks.provinz.bz.it/fanes-sennes-prags-fanes-senes-braiesnature-park.asp (accessed 24 May 2019).

Ballantyne, R., Hughes, K., Lee, J., Packer, J. and Sneddon, J. (2018), “Visitors' values and environmental learning outcomes at wildlife attractions: implications for interpretive practice", Tourism Management, Vol. 64, pp. 190-201.

Balmford, A., Green, J.M.H., Anderson, M., Beresford, J., Huang, C., Naidoo, R. and Manica, A. (2015), "Walk on the wild side: estimating the global magnitude of visits to protected areas", PLoS Biology, Vol. 13 No. 2.

Bigne, J.E., Andreu, L. and Gnoth, J. (2005), "The theme park experience: an analysis, of pleasure, arousal and satisfaction", Tourism Management, Vol. 26 No. 6, pp. 833-844.

Carr, N. (2009), "Animals in the tourism and leisure experience", Current Issues in Tourism, Vol. 12 Nos 5/6, pp. 409-411.

Curtin, S. (2010a), "What makes for memorable wildlife encounters? Revelations from 'serious' wildlife tourists", Journal of Ecotourism, Vol. 9 No. 2, pp. 149-168.

Duffy, R. and Moore, L. (2011), "Global regulations and local practices: the politics and governance of animal welfare in elephant tourism", Journal of Sustainable Tourism, Vol. 19 Nos 4/5, pp. 589-604.

Fennell, D. (2008), Ecotourism, 3th ed., Routledge, New York, NY.

Higginbottom, K. (2004), Wildlife Tourism: Impacts, Management and Planning, Common Ground Publishing Pty, Altona.

Hsu, T.K., Tsai, Y.F. and Wu, H.H. (2009), "The preference analysis for tourist choice of destination: a case study of Taiwan", Tourism Management, Vol. 30 No. 2, pp. 288-297. 
WHATT

12,4

Kamri, T. and Radam, A. (2013), "Visitors' visiting motivation: Bako national park, Sarawak", Procedia - Social and Behavioral Sciences, Vol. 101, pp. 495-505.

Markwell, K. (2015), "Birds, beasts and tourists: human - animals' relationships in tourism", in Markwell, K. (Ed.), Animals and Tourism: Understanding Diverse Relationships, Channel View Publications, Bristol/New York, NY.

Moorhouse, T.P. Dahlsjö, C.A.L. Baker, S.E. D’ Cruze, N.C. and Macdonald, D.W. (2015), “The customer isn't always right - conservation and animal welfare implications of the increasing demand for wildlife tourism. (è complete questo riferimento?)”.

Moscardo, G. (2008), "Understanding visitor experiences in captive, controlled, and non - captive wildlife-based tourism settings", Tourism Review International, Vol. 11 No. 3, pp. 213-223.

Mutanga, C.N., Vengesayi, S., Chikuta, O., Muboko, N. and Gandiwa, E. (2017), "Travel motivation and tourist satisfaction with wildlife tourism experiences in Gonarezhou and Matusadona national parks", Journal of Outdoor Recreation and Tourism, Vol. 20, pp. 1-18.

Newsome, D. and Hassell, S. (2014), "Tourism and conservation in Madagascar: the importance of Andasibe national park", Koedoe, Vol. 56 No. 2, pp. 1-8.

Newsome, D., Moore, S.A. and Dowling, R.K. (2002), Natural Area Tourism: Ecology, Impacts and Management, Channel View Publications, Clevedon.

Oh, C.O. and Hammitt, W.E. (2010), "Determining economic benefits of park trails: management implications", Journal of Park and Recreation Administration, Vol. 28 No. 2, pp. 94-107.

Orams, M.B. (2002), "Feeding wildlife as a tourism attraction: a review of issues and impacts", Tourism Management, Vol. 23 No. 3, pp. 281-293.

Pan, S. and Ryan, C. (2007), "Mountain areas and visitor usage - motivations and determinants of satisfaction: the case of Pirongia Forest park, New Zealand", Journal of Sustainable Tourism, Vol. 15 No. 3, pp. 288-308.

Reinius, S.W. and Fredman, P. (2007), "Protected areas as attractions", Annals of Tourism Research, Vol. 34 No. 4, pp. 839-854.

Reynolds, P.C. and Braithwaite, D. (2001), "Towards a conceptual framework for wildlife tourism", Tourism Management, Vol. 22 No. 1, pp. 31-42.

Rodger, K., Moore, S.A. and Newsome, D. (2007), "Wildlife tours in Australia: characteristics, the place of science and sustainable futures", Journal of Sustainable Tourism, Vol. 15 No. 2, pp. 160-179.

Rossell, J.C.G. (2017), "Animals in tourism studies", available at: www.youtube.com/watch? time_continue $=1 \& \mathrm{v}=\mathrm{QjK} 14 \mathrm{eFhCcA}$, or $\mathrm{http} / / /$ animaltourismfinland.com/?s=utilitarianism $\&$ submit=Search

Shackley, M. (1996), Wildlife Tourism, International Thomson Business Press, London.

Shackley, M., (Ed.) (1998), Visitor Management: Case Studies from World Heritage Sites, Butterworth Heinermann, Oxford.

Tian-Cole, S., Crompton, J. and Willson, V. (2002), "An empirical investigation of the relationships between service quality, satisfaction and behavioural intentions among visitors to a wildlife refuge", Journal of Leisure Research, Vol. 34 No. 1, pp. 1-24.

Wilson, E.O. (1993), "Biophilia and the conservation ethics", in Kellert, S.R. and Wilson, E.O. (Eds), The Biophilia Hypothesis, Island Press, Washington, DC.

World Tourism Organization (2015a), "Towards measuring the economic value of wildlife watching tourism in Africa - briefing paper", UNWTO, Madrid, available at: http://sdt.unwto.org/content/ unwto-briefing-wildlife-watching-tourism-africa (accessed 04 April 2019). 


\section{Appendix}

Encounters in

Descriptive statistics

\begin{tabular}{|c|c|c|c|c|c|c|c|}
\hline \multirow{2}{*}{\multicolumn{2}{|c|}{ Animal encounter }} & \multirow{2}{*}{$\begin{array}{c}\text { No encounter } \\
45 \% \\
\text { Strongly } \\
\text { disagree (\%) }\end{array}$} & \multirow{2}{*}{$\begin{array}{c}\text { Encounter } \\
56 \% \\
\text { Disagree } \\
(\%)\end{array}$} & \multirow{2}{*}{$\begin{array}{c}\text { Gender } \\
\text { Neutral } \\
(\%)\end{array}$} & \multirow{2}{*}{$\begin{array}{c}\text { Male } \\
35 \% \\
\text { Agree (\%) }\end{array}$} & \multirow{2}{*}{$\begin{array}{c}\text { Female } \\
65 \% \\
\text { Strongly } \\
\text { agree }(\%)\end{array}$} & \\
\hline & & & & & & & \\
\hline No & I am dissatisfied & 24.9 & 9.3 & 5.2 & 3.1 & 1.9 & \\
\hline encounter & $\begin{array}{l}\text { I will go out of } \\
\text { curiosity }\end{array}$ & 6.6 & 5.8 & 9.1 & 12.6 & 10.3 & \\
\hline Encounter & $\begin{array}{l}\text { The encounter } \\
\text { made me more } \\
\text { satisfied }\end{array}$ & 0.6 & 1.6 & 9.1 & 20.4 & 23.7 & \\
\hline \multirow{2}{*}{\multicolumn{2}{|c|}{$\begin{array}{l}\text { Satisfaction of the overall } \\
\text { experience at the park }\end{array}$}} & $\begin{array}{l}\text { Not at all } \\
\text { satisfied }\end{array}$ & $\begin{array}{c}\text { Not } \\
\text { satisfied }\end{array}$ & Neutral & Satisfied & $\begin{array}{c}\text { Very } \\
\text { satisfied }\end{array}$ & \\
\hline & & $0.8 \%$ & $3.3 \%$ & $13.6 \%$ & $26.2 \%$ & $54.6 \%$ & \\
\hline \multirow{2}{*}{\multicolumn{2}{|c|}{$\begin{array}{l}\text { Importance of the creation of } \\
\text { wildlife zones }\end{array}$}} & $\begin{array}{l}\text { Not at all } \\
\text { important }\end{array}$ & $\begin{array}{c}\text { Not } \\
\text { important }\end{array}$ & Neutral & Important & $\begin{array}{c}\text { Very } \\
\text { important }\end{array}$ & Table A1. \\
\hline & & $35.9 \%$ & $23.1 \%$ & $14.8 \%$ & $13.2 \%$ & $12.6 \%$ & Descriptive statistics \\
\hline
\end{tabular}


WHATT

12,4

454
How important are the following factors in choosing to visit this nature park?

$\begin{array}{ccccc}\begin{array}{c}\text { Not at all } \\ \text { important }(\%)\end{array} & \begin{array}{c}\text { Not important } \\ (\%)\end{array} & \begin{array}{c}\text { Neutral } \\ (\%)\end{array} & \begin{array}{c}\text { Very } \\ \text { Important } \\ (\%)\end{array} & \begin{array}{c}\text { important } \\ (\%)\end{array} \\ 1.2 & 0.4 & 2.2 & 13.5 & 82.8 \\ 5.9 & 6.5 & 13.3 & 29.7 & 44.6 \\ 5.0 & 8.1 & 23.0 & 32.9 & 31.1 \\ 2.4 & 8.7 & 25.0 & 26.5 & 37.4 \\ 4.6 & 10.5 & 20.6 & 27.3 & 37.0 \\ 6.1 & 14.7 & 23.0 & 24.6 & 31.7 \\ 0.8 & 1.0 & 5.5 & 22.6 & 70.1 \\ 0.6 & 0.4 & 2.6 & 9.7 & 86.7 \\ 0.8 & 3.0 & 12.1 & 24.2 & 60.0 \\ 1.4 & 3.2 & 11.1 & 24.0 & 60.4 \\ 2.6 & 5.1 & 14.3 & 18.2 & 59.8\end{array}$

Stay in touch with nature

Spend some time with the family

Practice sport

See wild animals

Visit a place

Photograph fauna/flora

Immerse into nature

Admire the landscape beauty

Relax and have fun

Escape daily routine

Escape city chaos

During your last visit, you might have had the opportunity to encounter wildlife. How important do you rate the following factors to enjoy a satisfying experience with wild animals?

Number of species encountered

Variety of species encountered

$7.8 \quad 20.5$

Ease in sighting animals

5.4

13.3

34.0

23.5

30.2

14.1

Ease in approaching animals

6.4

17.3

30.0

29.0

21.1

Observe animals in their natural 16.3

31.8

32.8
29.0

15.3

14.5

habitat

Level of perceived security

2.6

4.4

15.1

21.5

30.8

56.3

6.2

$10.7 \quad 24.5$

27.8

How much do you agree with the following statements concerning a possible encounter with wildife?

$\begin{array}{ccccc}\begin{array}{c}\text { Strongly } \\ \text { disagree (\%) }\end{array} & \text { Disagree (\%) } & \begin{array}{c}\text { Neutral } \\ (\%)\end{array} & \text { Agree (\%) } & \begin{array}{c}\text { Strongly } \\ \text { agree }(\%)\end{array} \\ 13.9 & 27.4 & 36.4 & 14.9 & 7.4 \\ 16.2 & 31.9 & 31.9 & 13.9 & 6.1 \\ 16.0 & 31.7 & 29.7 & 15.7 & 7.0 \\ 13.7 & 20.9 & 22.9 & 23.9 & 18.6 \\ 46.0 & 27.8 & 16.8 & 6.1 & 3.3\end{array}$

Longer encounter

See big animals

See popular animals

See endangered species

See dangerous animals

46.0

27.8

16.8

6.1

3.3

For the benefit of one or more species, how much would you be willing to revise the rules of your stay/visit during the experience in nature?

Forgo the opportunity to visit some areas during predetermined periods Participate in conservation projects

\begin{tabular}{crrrc} 
Not at all (\%) & No (\%) & $\begin{array}{c}\text { Neutral } \\
(\%)\end{array}$ & \multicolumn{2}{c}{$\begin{array}{c}\text { Very } \\
\text { Willing }(\%)\end{array}$} \\
3.3 & 4.1 & 12.6 & 26.0 & 54.0 \\
3.9 & 12.6 & 24.5 & 23.3 & 35.7 \\
1.2 & 2.3 & 8.7 & 20.4 & 67.4 \\
& & & & \\
3.9 & 9.7 & 15.9 & 25.4 & 45.2 \\
\hline
\end{tabular}

Table A2.

Reduce car/motorbike speed in the natural park

Reduce the number of sporting

Descriptive statistics

activities with the highest impact on

fauna 

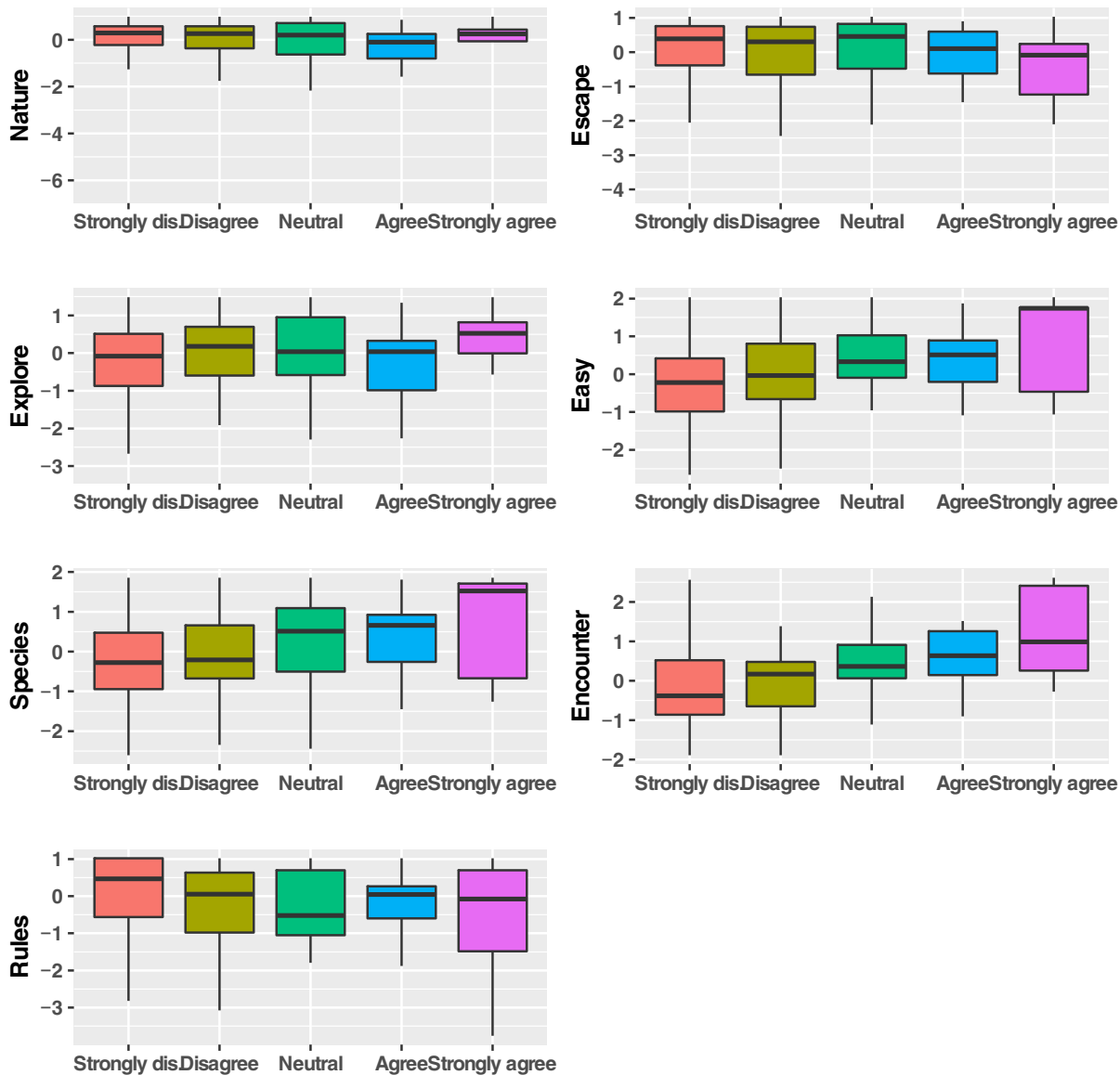

Figure A1.

FD boxplots of "I'm dissatisfied" (no encounters with animals) 
WHATT

12,4

456
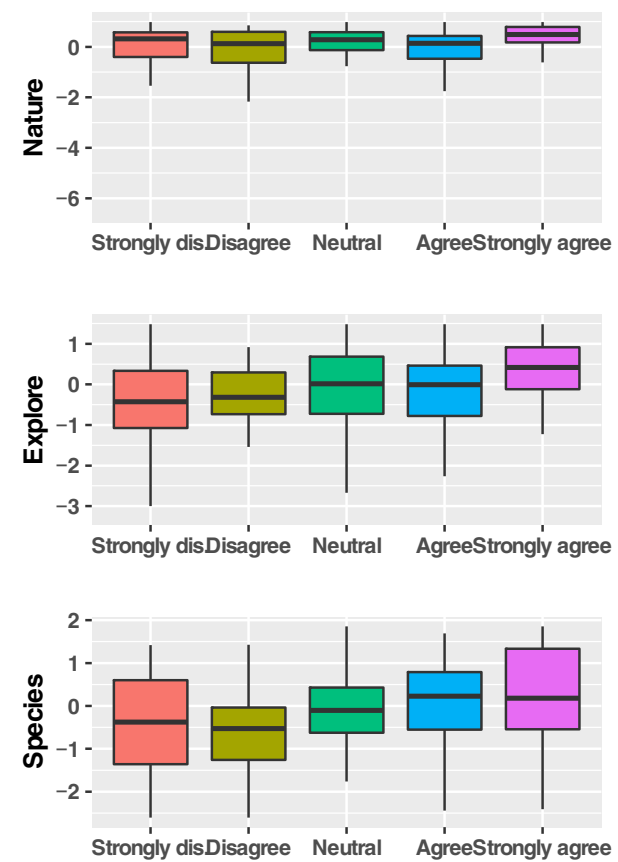

Figure A2.

FD boxplots of "I will come for curiosity to see any of them" (no encounters with animals)
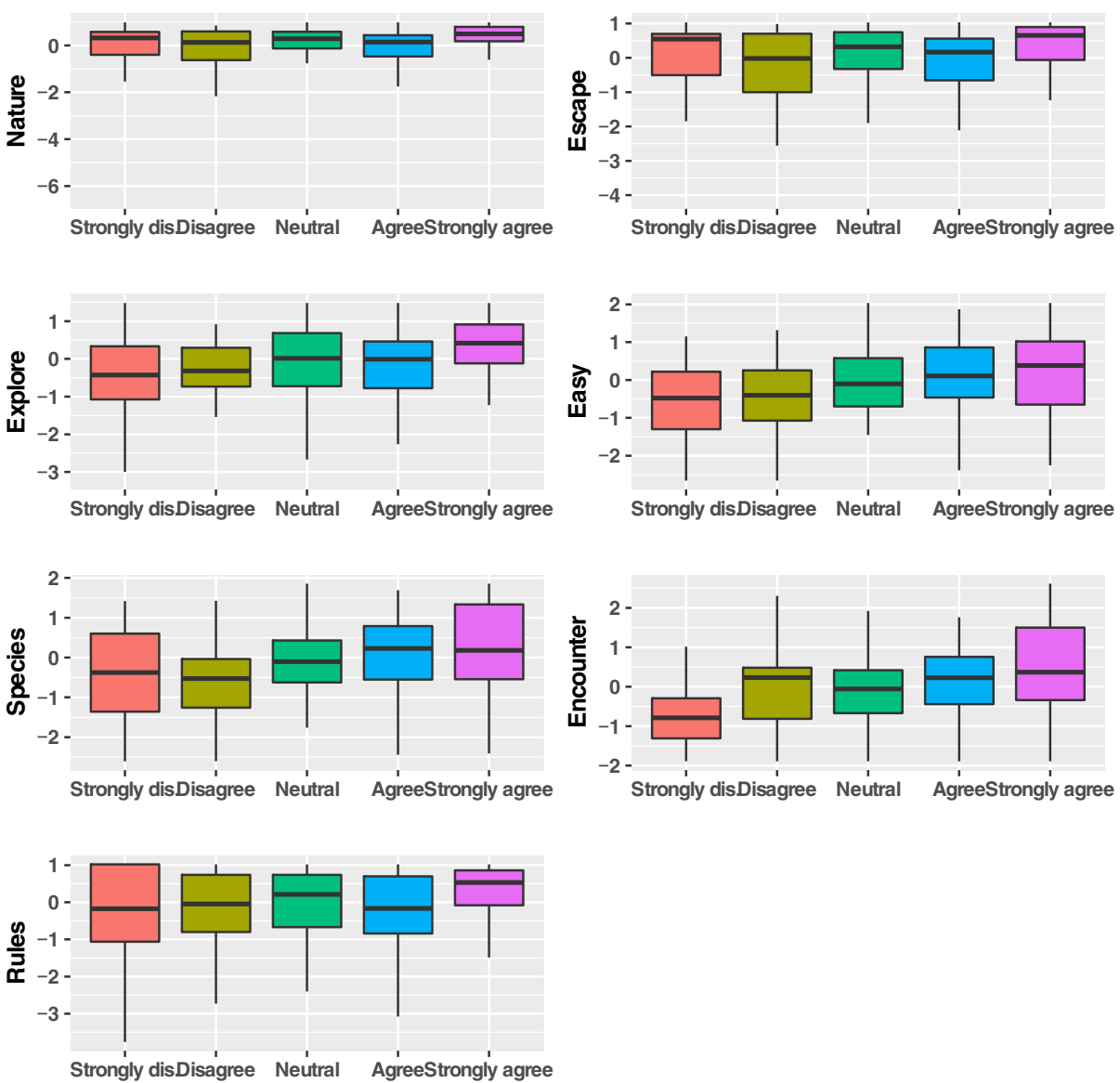

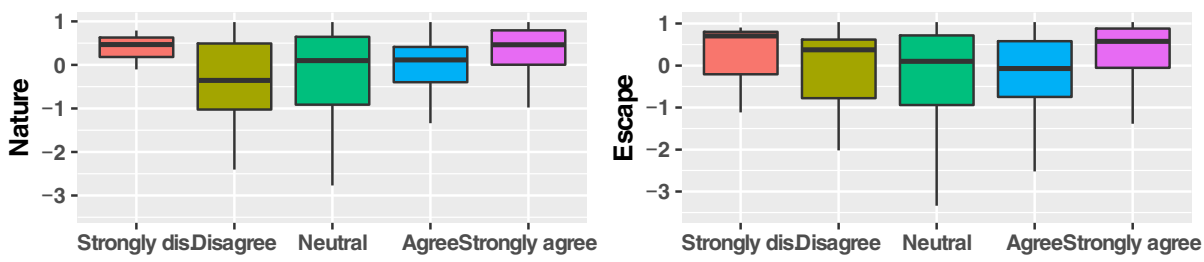

Encounters in protected areas
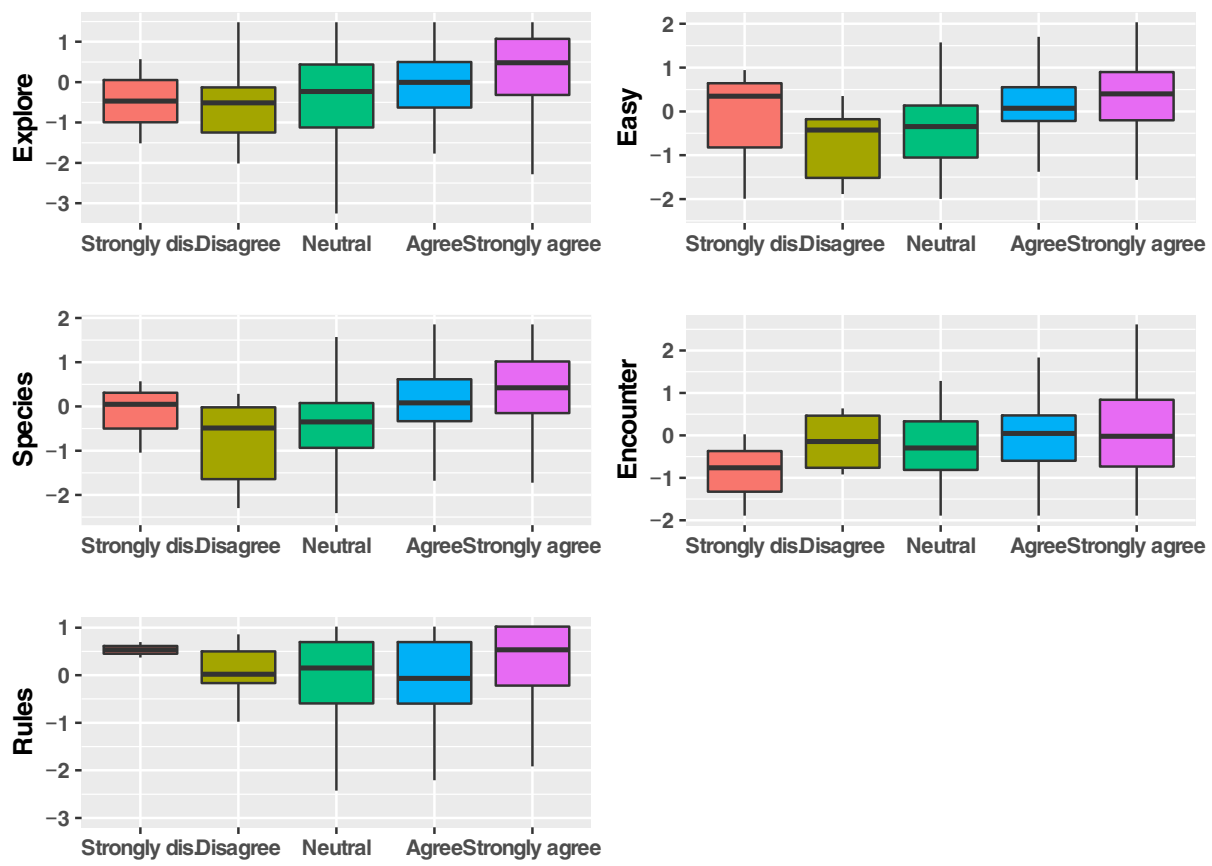

Figure A3.

FD boxplots for "It made me more satisfied about the experience" (encounters with animals) 
WHATT

12,4

458
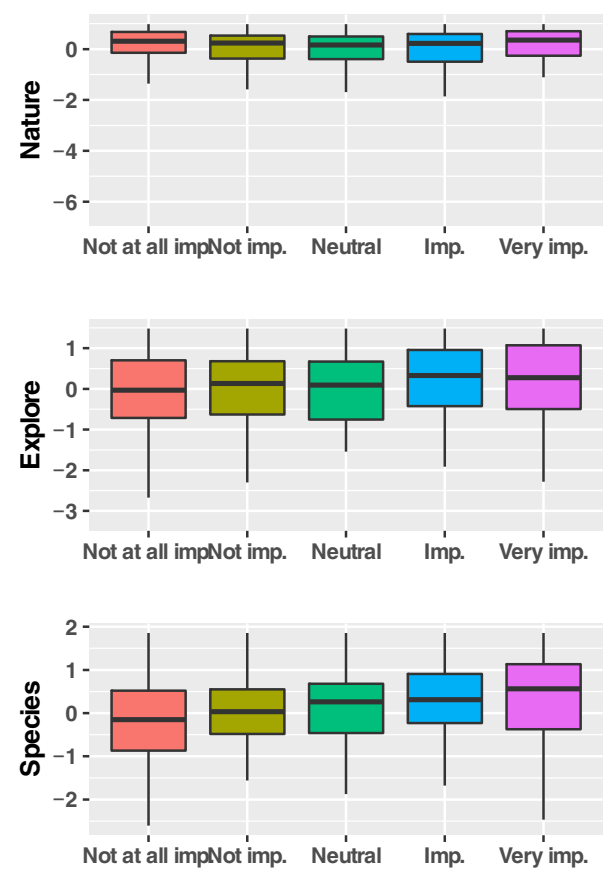

Figure A4.

FD boxplots of the importance of "Creating wildlife zones"
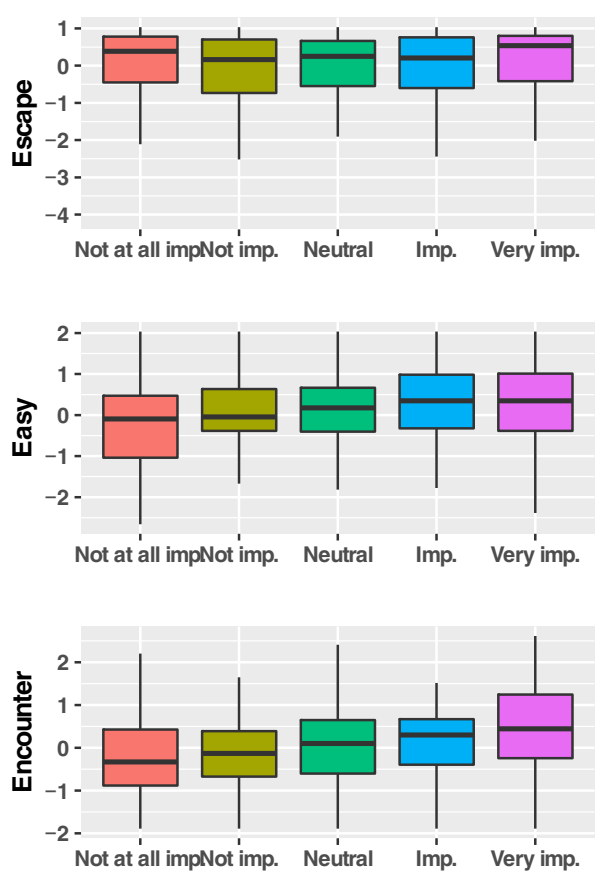

\section{Corresponding author}

Linda Osti can be contacted at: Linda.Osti@unibz.it

For instructions on how to order reprints of this article, please visit our website: www.emeraldgrouppublishing.com/licensing/reprints.htm

Or contact us for further details: permissions@emeraldinsight.com 